\title{
Rapid Simulation Model Building in Cellular Manufacturing using Cladistics Technique
}

\author{
Zainal Rasyid Mahayuddin ${ }^{\# 1}$, Nur Afiqah Khairuddin ${ }^{\# 2}$ \\ ${ }^{\#}$ Center for Artificial Intelligence Technology (CAIT), Faculty of Information Science and Technology, \\ Universiti Kebangsaan Malaysia (UKM), 43600 Bangi, Selangor Malaysia \\ E-mail: ${ }^{1}$ zainalr@ukm.edu.my, ${ }^{2}$ afiqahka@siswa.ukm.edu.my
}

\begin{abstract}
This paper describes rapid simulation model building using one of the classification approach called as Cladistics. There are many problems occurred in cellular manufacturing, and cladistics technique is used to classify all problems identified in this research. Cladistics is a common technique used by biologist to determine species and specimen based on the evolutionary analysis. In this research, cellular manufacturing problems are grouped based on their evolution. The purpose of the classification is to develop a rapid simulation prototype for model building. The prototype provides a user interface that linked to the templates developed and simulation engine. The prototype can be used to facilitate users in model building to reduce model development times especially for those who do not have any experience in simulation modelling.
\end{abstract}

Keywords - model building; simulation; cladistics; cellular manufacturing

\section{INTRODUCTION}

Computer simulation provides a better analysing technique, especially for complex stochastic systems. Model building is one of the keys for computer simulation [1] [2]. The objective of this research is to develop a rapid prototype to build simulation and modeling using cladistics technique. This paper focuses on the prototype development phase with two stages which are template development and user interface development. Physical elements and performance measure elements are clustered to become a template in order to reduce model-building time. Cellular manufacturing in 21 st century obviously faced with various challenging demands. Thus, there are many problems have been reported in cellular manufacturing industries. The key findings show that the main issues in cellular manufacturing are related to the formation of cells and generation of product families [3]. In order to solve various problems in cellular manufacturing, simulation can be one of the best options available [4]. Sheet metal forming is one of the manufacturing industries using simulation technology [21]. Another example for simulation application is missile manufacturing related to military [22]. Cladistics, an extensive tool which is used in biology is exploited in this study [5]. In addition, cladistics is also known as phylogenetic systems [6]. It is very useful to track the evolution of problems in cellular manufacturing as cladistics technique enable to produce an evolution [7]. Cladistics technique is the efficient way to implement in manufacturing system because it uses evolutionary analysis to present the relationship of its subjects. In this research, cellular manufacturing problems are the subjects and cause factors become the characteristic data.

\section{MATERIAL AND MethoD}

\section{A. Stage 1: Data Collection}

Data were collected by means of document analysis such as journals, academic articles, books and research papers. The search strategy focused on cellular manufacturing issues. Some of the keywords available used are "cellular manufacturing', 'cell formation' and 'manufacturing cells'. The results revealed almost 100 of papers were chosen, and 22 problems with 25 factors were extracted from data collection.

\section{B. Stage 2: Classifications of Problem}

Stage 2 is a phase which problems in cellular manufacturing are classified using specific software such as Mesquite and Winclada. It is proved that cladistics has been applied to manufacturing systems in order to distinguish present from past systems by improving the efficiency of manufacturing systems [7] - [13]. In this research, establishing a matrix table is the first step before using data as input in the cladogram development. Problems and factors in cellular manufacturing are chosen as taxa and characteristics of the cladogram. The main objective of 
constructing the cladogram is to generate a cladogram that has minimum steps and length [14]. Table 1 shows characters and states used in established cladogram. Table 2 shows data matrix created based on data collection in stage I. From data collected, binary number; 1 represents present of characters and 0 represent the absence of characters in the matrix above was inserted in specific cladogram generated software to establish a cladogram.

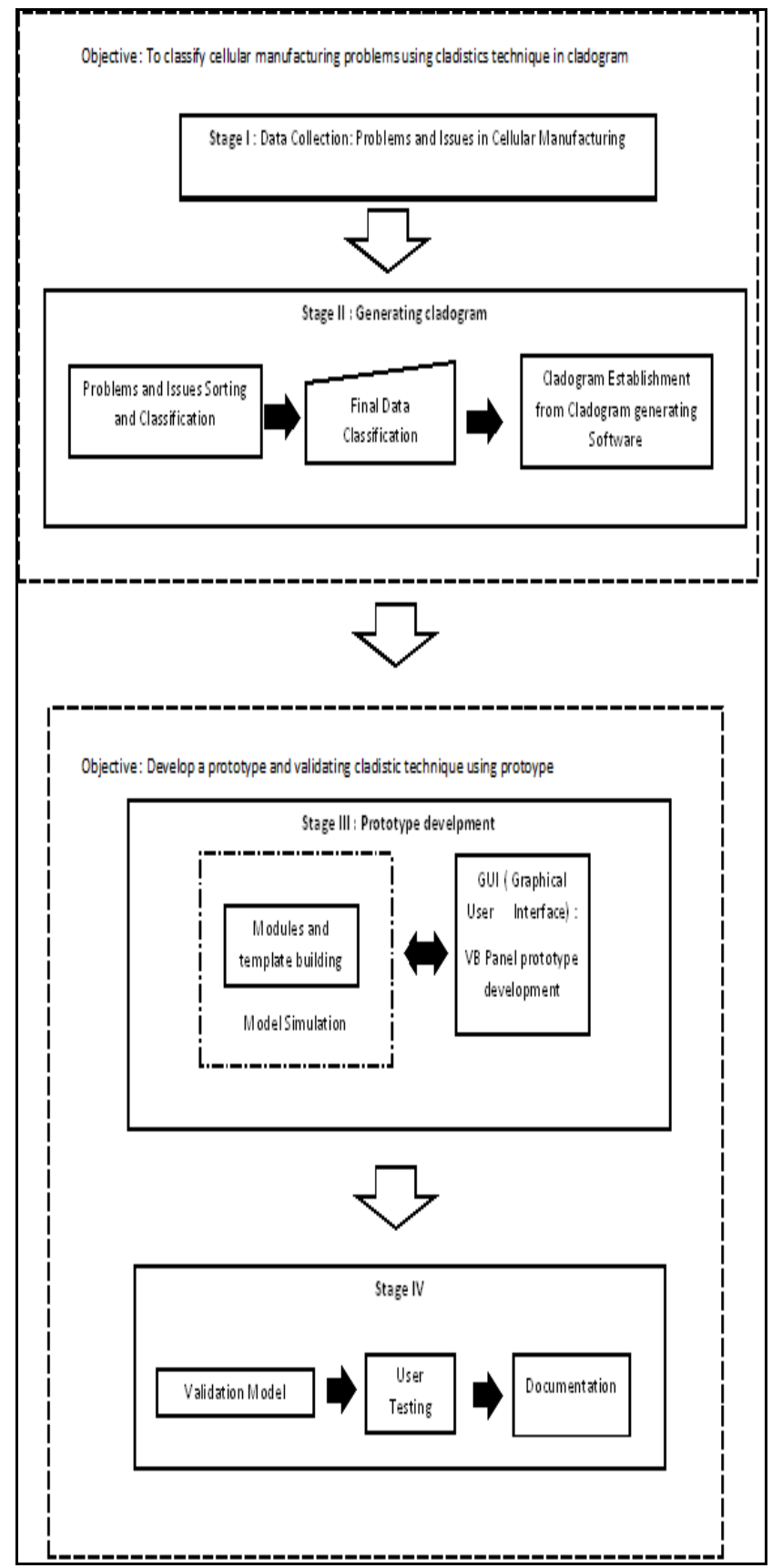

Fig. 1 Framework of prototype development

Fig. 2 shows problems listed in cladogram based on factors identified. Block of the module in simulation software is coded as a template as shown in Fig. 3.
TABLE I

CHARACTERS AND STATES

\begin{tabular}{|c|c|c|c|c|c|c|}
\hline & FACTORS & States & \multicolumn{3}{|c|}{ Performance Measure } & \\
\hline \multirow[t]{2}{*}{1} & ecxessive scrap & 0 & Absence & & & \\
\hline & & 1 & Scrap rate & & & \\
\hline \multirow[t]{2}{*}{2} & Rework & 0 & Absence & & & \\
\hline & & 1 & Rework c & & & \\
\hline \multirow[t]{2}{*}{3} & Lack of coordination & 0 & Absence & & & \\
\hline & (labour) & 1 & Labor effi & iency & & \\
\hline \multirow[t]{2}{*}{4} & Flexibility of worker & 0 & Absence & & & \\
\hline & & 1 & Workload & & & \\
\hline \multirow[t]{2}{*}{5} & Efficiency training & 0 & Absence & & & \\
\hline & for workers & 1 & Labor effi & iency & & \\
\hline \multirow[t]{2}{*}{6} & Productivity low & 0 & Absence & & & \\
\hline & & 1 & Production & volume & & \\
\hline \multirow[t]{2}{*}{7} & Lack of product & 0 & Absence & & & \\
\hline & understanding & 1 & Production & volume & & \\
\hline \multirow[t]{2}{*}{8} & Excessive inventories & 0 & Absence & & & \\
\hline & & 1 & WIP Inve & tory & & \\
\hline \multirow[t]{2}{*}{9} & High machine & 0 & Absence & & & \\
\hline & breakdown & 1 & maintenan & cost & & \\
\hline \multirow[t]{2}{*}{10} & Machine utilization & 0 & Absence & & & \\
\hline & & 1 & Machine & fficiency & & \\
\hline \multirow[t]{2}{*}{11} & No. of machines & 0 & Absence & & & \\
\hline & more than no of worker & 1 & Labor effi & iency & & \\
\hline \multirow[t]{2}{*}{12} & High equipment cost & 0 & Absence & & & \\
\hline & & 1 & Total cost & & & \\
\hline \multirow[t]{2}{*}{13} & High allocation of machine cost & 0 & Absence & & & \\
\hline & & 1 & Total cost & & & \\
\hline \multirow[t]{2}{*}{14} & Setup time & 0 & Absence & & & \\
\hline & & 1 & Setup cos & & & \\
\hline \multirow[t]{2}{*}{15} & Total delay time & 0 & Absence & & & \\
\hline & & 1 & Backorde & cost (dela & delive & \\
\hline \multirow[t]{2}{*}{16} & Bottleneck/ total waiting & 0 & Absence & & & \\
\hline & & 1 & Delivery & ime perfor & nance & \\
\hline 17 & Lead time & 0 & Absence & & & \\
\hline & & 1 & Production & volume/ $\mathrm{p}$ & odustic & \\
\hline 18 & high setup cost & 0 & Absence & & & \\
\hline & & 1 & Total cost & & & \\
\hline 19 & high operation cost & 0 & Absence & & & \\
\hline & & 1 & Total cost & & & \\
\hline 20 & high reconfiguration cost & 0 & Absence & & & \\
\hline & & 1 & Total cost & & & \\
\hline 21 & High intercellular movement distance & 0 & Absence & & & \\
\hline & & 1 & material h & indling $\cos$ & & \\
\hline 22 & High intracellular movemnet distance & 0 & Absence & & & \\
\hline & & 1 & material h & indling $\cos$ & & \\
\hline 23 & Space limitation & 0 & Absence & & & \\
\hline & & 1 & intra/inter & cellular mo & ement & \\
\hline 24 & Machine capacity & 0 & Absence & & & \\
\hline & & 1 & Machine & fficiency & & \\
\hline 25 & Operation time & 0 & Absence & & & \\
\hline & & 1 & Productio & ivolume/ & & \\
\hline
\end{tabular}

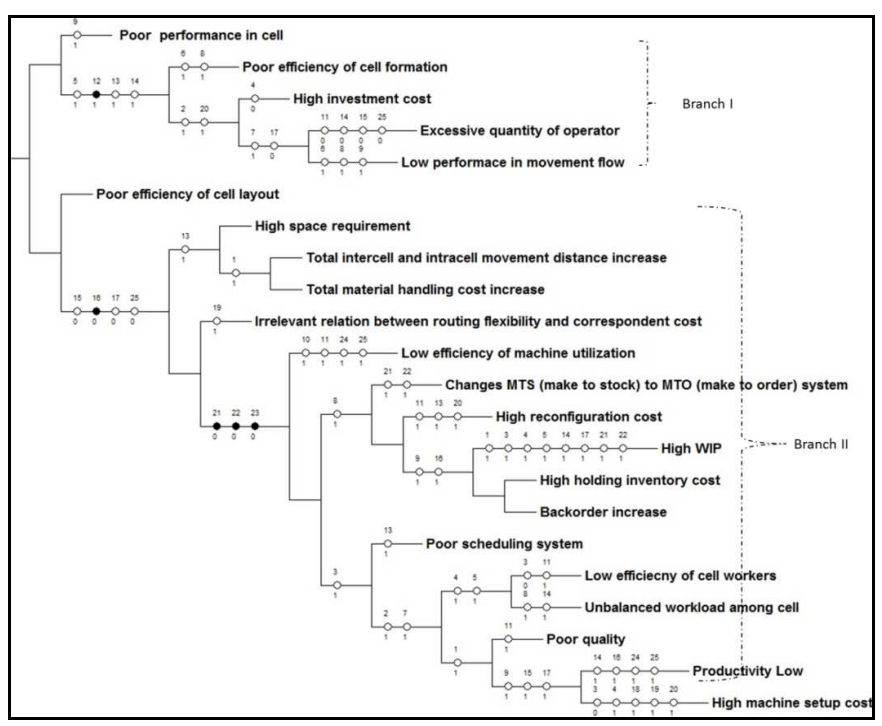

Fig. 2 Cellular manufacturing problem cladogram 
TABLE II

DATA MATRIX

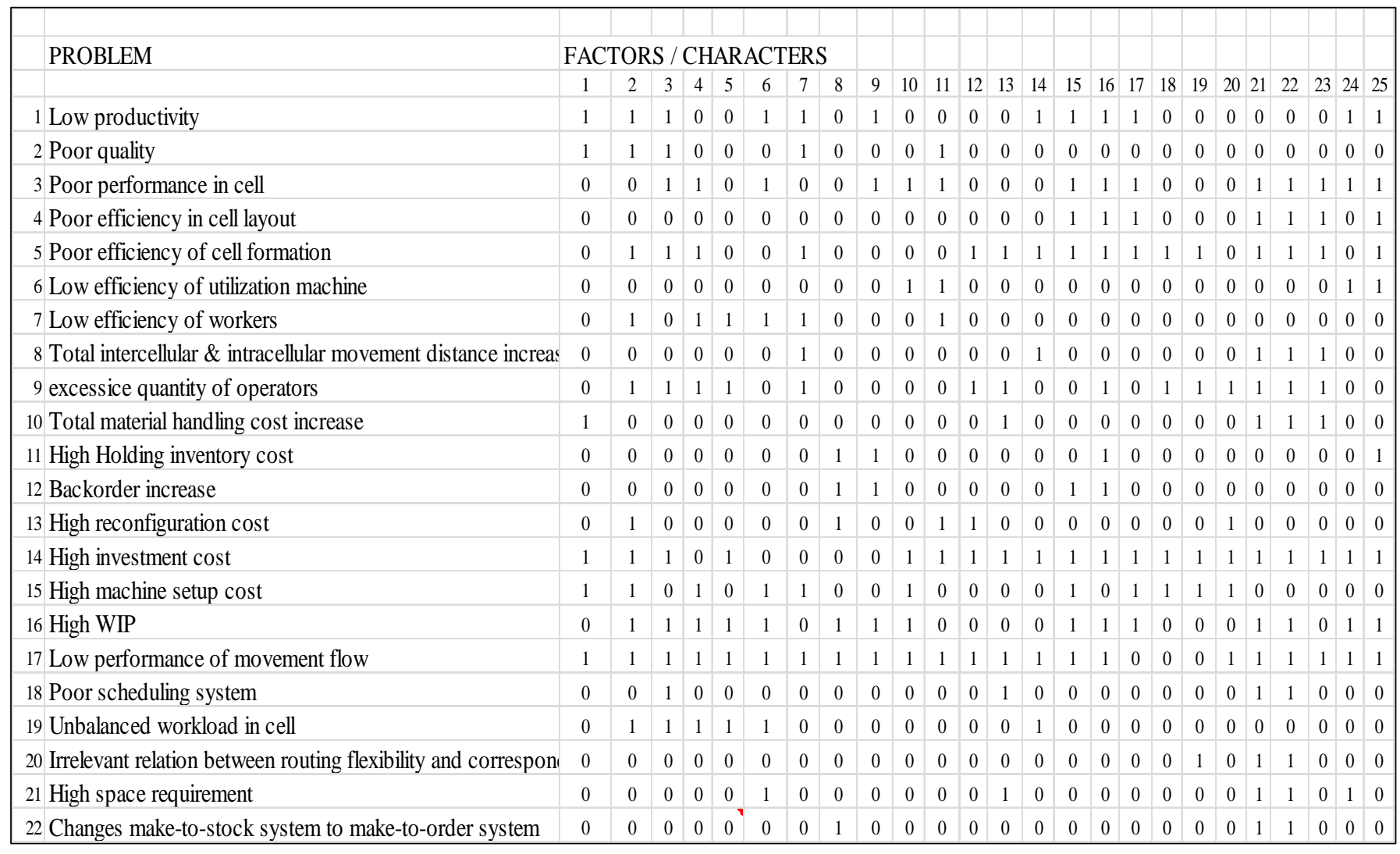

\section{Stage 3: Development of Rapid Prototype}

This section shows the development of a prototype, which consists two phases; developing templates and modules in simulation panel, and developing user interface using VBA.

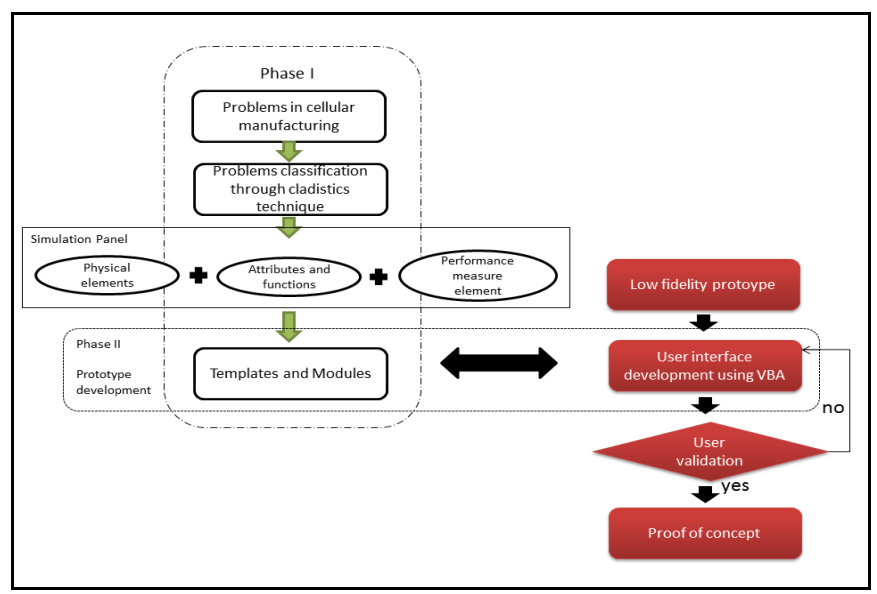

Fig. 3 Prototype development

Fig. 3 shows the process of prototype development in stage III. There are two phases, which are template development and user interface development. Phase I requires physical attributes, performance measures element and functions to build a template. Phase II use Visual Basic Application to build a user panel to send input data to simulation panel.
Fig. 4 describes template development based on the cladogram. VB second user interface enables the user to build the desired model according to the template. Novice modeller does not need to arrange physical elements manually as modules created according to cells.

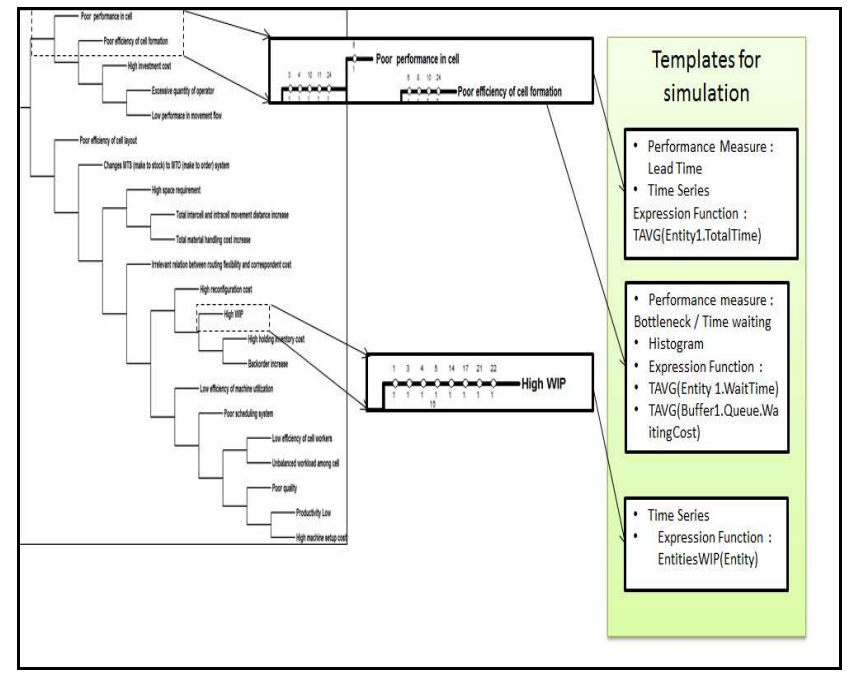

Fig. 4 Template development based on cladogram

Fig. 5 shows the main panel of the prototype developed. Few frames specify the functions of the prototype such as modules, single elements, and simulation panel button. Modules created were specifically for cellular manufacturing which cluster elements based on problems. Performance 
measure button is added to open performance measure panel in order to insert an element of the performance measure.

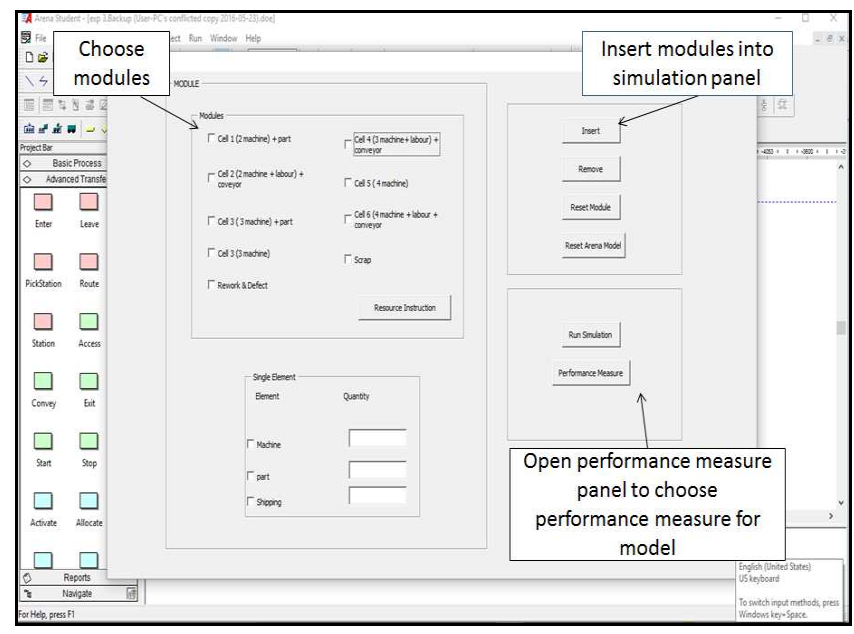

Fig. 5 VBA main control panel

Based on Fig. 6, a model based on high work in process problem was built using rapid prototype. Based on the problem, three processes required in the model. From the prototype, cell 3 that consists of three machines and incoming part were select and insert into simulation panel.

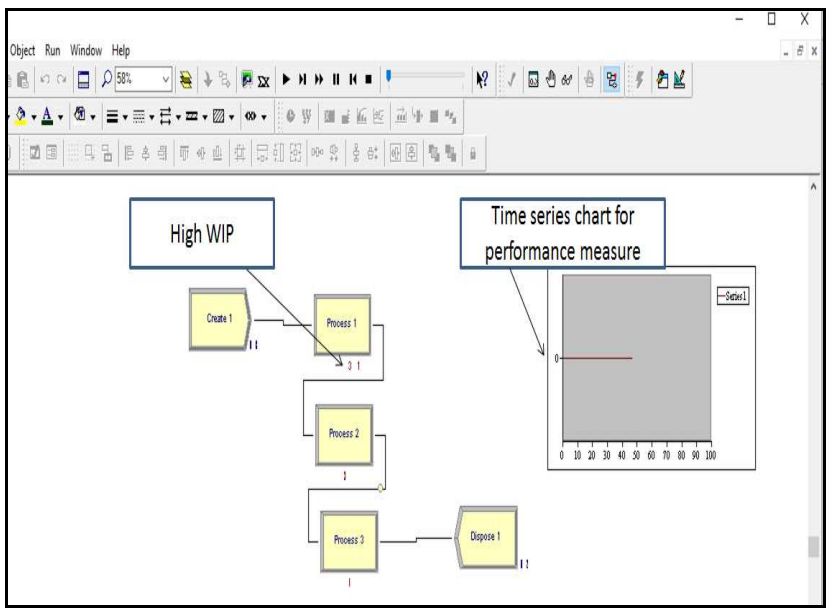

Fig. 6 Model development and performance measure

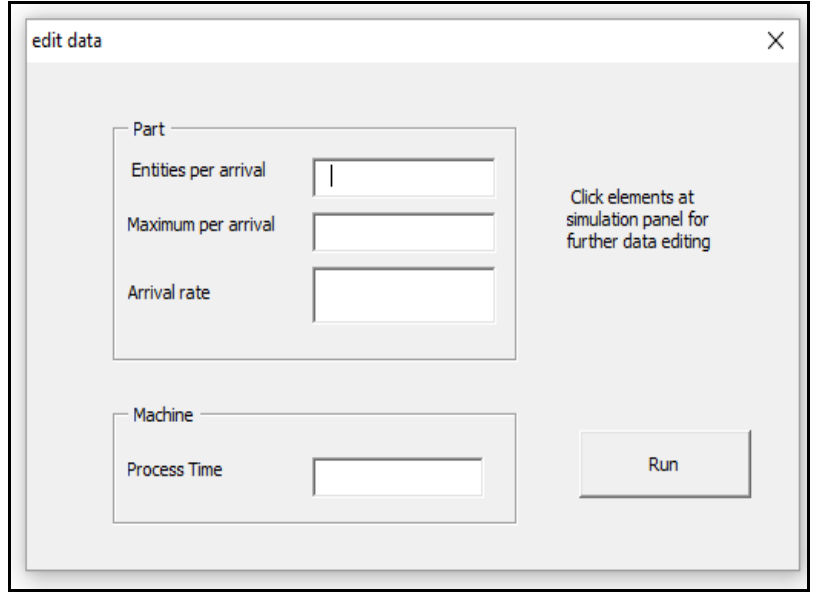

Fig. 7 Edit data panel

Basic data needed to simulate the problem was inserted such as; entities per arrival, process time, maximum per arrival, and arrival rate as shown in Fig. 7. Specific data such as resources details must be inserted manually at the simulation panel.

Fig. 8 shows the appeared control panel after simulation activity end. The panel allows the user to edit the existing model or to abort the model.

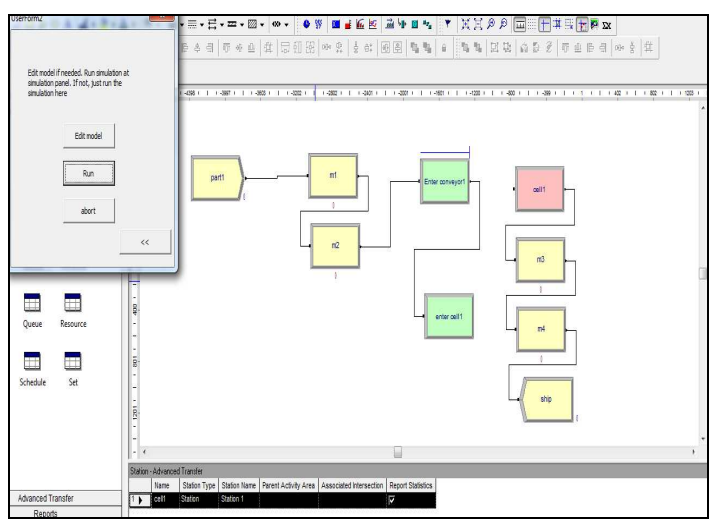

Fig. 8 Control the simulation activity

Fig. 9 shows the enlarged control panel used to control the simulation activity in the simulation panel. There are three buttons, which are edit model button, run button and abort button. By clicking the edit model button, edit data panel in Fig. 7 will appear. By clicking abort button, simulation activity will stop. Another message box will appear to ask the user to proceed another model building or exit simulation panel.

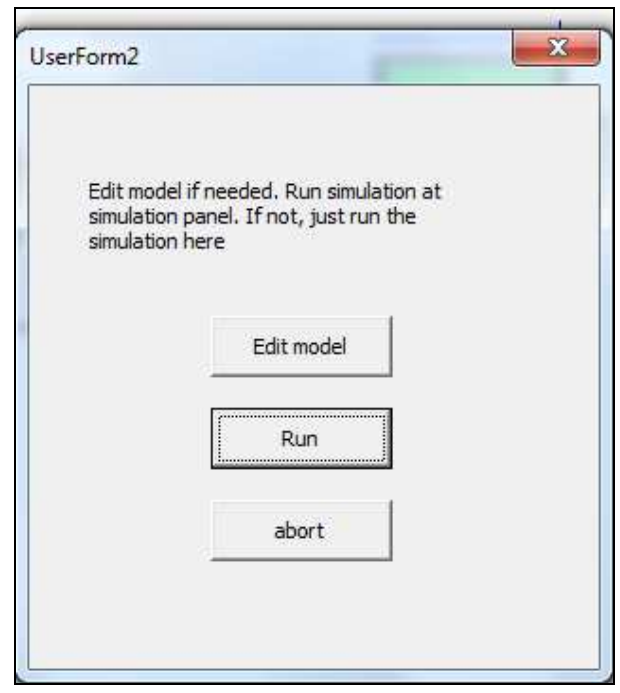

Fig. 9 Control panel to run the simulation

Fig. 10 shows a performance measure panel required by models to analyse the simulation using charts. Based on a model in Fig.6 WIP performance measure applied "EntitiesWIP (Entity Type)" function expression to calculate total WIP in the system. 


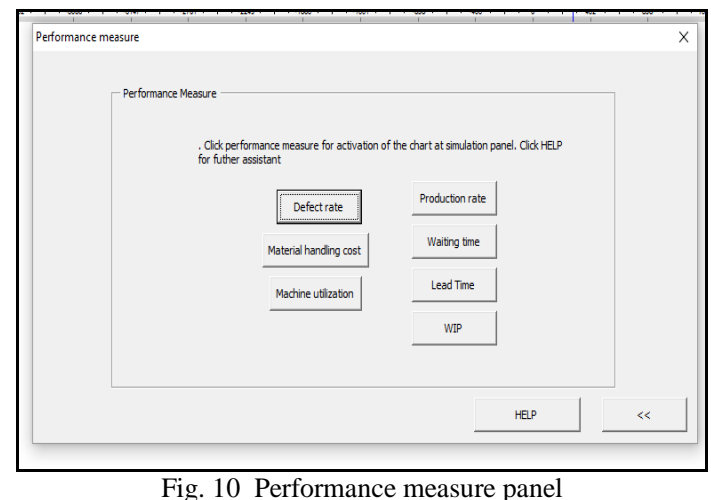

In addition, the prototype provides inexperienced user to use required element resources if needed as shown in Fig. 11. Proper instructions and guidance are provided to bring convenience to users.

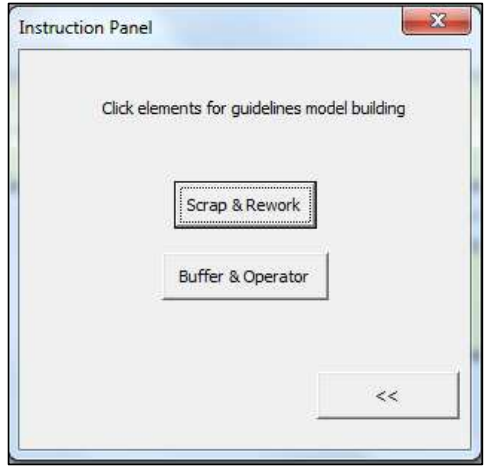

Fig. 11 Model resource control panel

\section{RESULT AND DISCUSSION}

This section briefly shows the result obtained after user testing was done. The score was given based on ranking 1 (Totally Disagree) to 5 (Totally Agree). The results obtained based on user testing and evaluation. There are two forms provided. The first evaluation is model-building exercises and the second evaluation is user feedback evaluation. Participant chosen consisted by the inexperienced user with less than 3 months model-building experiences.

TABLE III

Pilot TESTING

Mode A : Manual Model Building

\begin{tabular}{|l|c|c|}
\hline & Masa (min) & Evaluation \\
\hline Exercise 1 & $10: 23$ & 4 (Easy) \\
\hline Exercise 2 i & $11: 21$ & 2(Difficult) \\
\hline Exercise 2 ii & Cannot proceed & 5(Easy) \\
\hline Exercise 2 iii & Cannot proceed & 1(Very Difficult) \\
\hline Exercise 3 i & $12: 30$ & 4(Easy) \\
\hline Exercise 3 ii & $6: 06$ & 2(Difficult) \\
\hline Exercise 3 iii & Cannot proceed & 2(Difficult) \\
\hline
\end{tabular}

Mod B: Model Building using Prototype

\begin{tabular}{|l|c|c|}
\hline & Masa (min) & Evaluation \\
\hline Exercise 1 & $5: 16$ & 5(Very Easy) \\
\hline Exercise 2 i & Cannot proceed & 2(Difficult) \\
\hline Exercise 2 ii & Cannot proceed & 5(Very Easy) \\
\hline Exercise 2 iii & Cannot proceed & 4(Easy) \\
\hline Exercise 3 i & $3: 02$ & 5(Very Easy) \\
\hline Exercise 3 ii & $4: 56$ & 2(Difficult) \\
\hline Exercise 3 iii & $5: 09$ & 2(Difficult) \\
\hline
\end{tabular}

Table 3 shows the result of pilot testing before improvements of the prototype was made. From the table above, it is shown that model building time manually takes longer than using prototype. Besides that, there are few exercises that cannot proceed by participants because of certain technical problems. Some of the problems are there are no elements needed provided in the prototype. Thus participant had to drag manually from simulation panel. Besides that, participants enable to understand guidelines given from the model building exercises.

Participants chosen to participate in the testing had less than 6 months experiences in simulation and modeling. This is because the prototype was made to be used by beginner or novice. Simulation and modeling is a complicated process. Thus this prototype enables novice modeller to build model and simulation. Based on the results of evaluation in Table 3 above, evaluation made with two sections, which are the first section evaluate the ease of use of the prototype. Table 3 shows the respondents of the user testing experienced a little difficulty when using the prototype because according to them the guidelines prepared was not understandable. Thus, most of them gave score 3 for guideline issues. The average score for the prototype in terms of ease of use is $56.67 \%$.

However, this prototype is proven can be useful in simulation and modeling building as the average score for usefulness aspect is $76.67 \%$. In addition, it is agreeable that model-building time can be reduced as two over three participants gave (4) and (5) score for that aspect. A part from that, performance measure aspect got average (4) score which means the participants agreed it is easy to insert performance measure in order to analyse the simulation output. Even though performance measure was agreed easy to use, the usefulness of performance measure got average scores as some of the attributes and functions of performance measures need to insert manually. A part from that, participants involved believed the potential of the prototype to increase simulation building is 3.33 out of 5 scores. It is because there are few aspects that can be improved based on the scores given. 
TABLE IV

REsult OF Evaluation

\begin{tabular}{|c|c|c|c|c|}
\hline & \begin{tabular}{|c|} 
First \\
student
\end{tabular} & \begin{tabular}{c|}
$\begin{array}{c}\text { Second } \\
\text { student }\end{array}$ \\
\end{tabular} & $\begin{array}{c}\text { Third } \\
\text { student }\end{array}$ & \begin{tabular}{|c|}
$\begin{array}{c}\text { Average } \\
\text { Score }\end{array}$ \\
\end{tabular} \\
\hline \multicolumn{5}{|c|}{ 1)Duration involve in simulation and modeling } \\
\hline \multicolumn{5}{|c|}{\begin{tabular}{|l|l|l|l|} 
Never & & & \\
\end{tabular}} \\
\hline 0-6 months & $\bullet$ & - & - & \\
\hline \multicolumn{5}{|l|}{ 6-12 months } \\
\hline \multicolumn{5}{|c|}{\begin{tabular}{|l|l|l|}
$\begin{array}{l}\text { More than } 12 \\
\text { months }\end{array}$ & & \\
\end{tabular}} \\
\hline \multicolumn{5}{|c|}{ 2)User Experience in ARENA } \\
\hline Lesson in lecture & $\bullet$ & $\bullet$ & & \\
\hline \multicolumn{5}{|l|}{ Group project } \\
\hline \multicolumn{5}{|l|}{ Thesis project } \\
\hline Other than above & & & $\bullet$ & \\
\hline \multicolumn{5}{|l|}{ 3) Ease of use } \\
\hline $\begin{array}{l}\text { The prototype is } \\
\text { easy to use }\end{array}$ & 4 & 3 & 2 & 3 \\
\hline $\begin{array}{l}\text { Guideline given } \\
\text { is } \\
\text { understandable } \\
\end{array}$ & 3 & 2 & 3 & 2.67 \\
\hline \multirow{2}{*}{\multicolumn{5}{|c|}{$\begin{array}{l}\text { Score } \\
56.67 \% \\
\text { 4)Usefulness of prototype } \\
\end{array}$}} \\
\hline & & & & \\
\hline $\begin{array}{l}\text { The prototype is } \\
\text { very useful in } \\
\text { building } \\
\text { model the }\end{array}$ & 5 & 4 & 3 & 4 \\
\hline $\begin{array}{l}\text { The prototype can } \\
\text { reduce time model } \\
\text { building }\end{array}$ & 5 & 4 & 3 & 4 \\
\hline $\begin{array}{l}\text { Physical element } \\
\text { can be created } \\
\text { easily }\end{array}$ & 5 & 4 & 4 & 4.33 \\
\hline $\begin{array}{l}\text { Performance } \\
\text { measure can be } \\
\text { created easily }\end{array}$ & 4 & 4 & 4 & 4 \\
\hline $\begin{array}{l}\text { Performance } \\
\text { measure element } \\
\text { is very useful for } \\
\text { modeling } \\
\text { simulation } \\
\text { building }\end{array}$ & 4 & 3 & 3 & 3.33 \\
\hline $\begin{array}{l}\text { The prototype has } \\
\text { a potential to } \\
\text { increase } \\
\text { simulation } \\
\text { modeling building }\end{array}$ & 3 & 3 & 4 & 3.33 \\
\hline $\begin{array}{l}\text { Average score } \\
\text { percentage }\end{array}$ & & & & $\begin{array}{l}76.67 \\
\%\end{array}$ \\
\hline
\end{tabular}

\section{CONCLUSIONS}

The main objective of the research is to develop rapid prototype using cladistics technique to reduce model building. Many improvements can be made in this research such as adding features in the user interface control panel and adding problems into cladogram constructions in order to build a high efficiency prototype. The problems in cellular manufacturing are classified according to the chosen characteristics will enable to track down the most critical factors. Issues in cellular manufacturing are commonly caused by critical factors. In addition, the prototype can be a very useful tool to the novice modeler and there will be contribution to simulation modeling area.

\section{ACKNOWLEDGMENT}

This research is supported by Ministry of Higher Education Malaysia Research Grant Scheme of FRGS/2/2013/ICT01/UKM/02/4 Scheme of FRGS/2/2013/ICT01/UKM/02/4

\section{REFERENCES}

[1]. K. N.,Afiqah, \& Z. R. Mahayuddin, "Simulation Modeling by Classification of Problems: A Case of Cellular Manufacturing". IOP Conference Series: Materials Science and Engineering, 114, 012087. doi:10.1088/1757-899X/114/1/012087, 2015

[2]. Z.R. Mahayuddin , and B. Tjahjono, "Rapid Simulation Model Building through Classification of Problems: a Case of Manufacturing Assembly Lines," Int. Conf. Electr. Eng. Informatics.2011.

[3]. A. Negahban,, \& J.S. Smith. "Simulation for manufacturing system design and operation: Literature review and analysis". Journal of Manufacturing $\quad$ Systems, 33(2), 241-261. doi:10.1016/j.jmsy.2013.12.007, 2014

[4]. Mats Jägstam, \& P. Klingstam, "A handbook for integrating discrete event simulation as an aid in conceptual design of manufacturing systems.” In Simulation Conference, 2002. Proceedings of the Winter (pp. 1940 - 1944 (vol2))

[5]. W. Hennig, GrundzugeeinerTeorie der phylogenetischenSytematic. Deutsche Zentralverlag, Berlin.1950.

[6]. D. Lipscomb, Basics of Cladistic Analysis. Washington D.C.1998.

[7]. J.S Baldwin, C. Rose-Anderssen, K. Ridgway, F. Boettinger, M. Michen, K. Agyapong-Kodua, I. ,Brencsics, I. Nemeth, \& R. Krain, "The Evolution of Manufacturing SPECIES".Procedia CIRP, vol. 7 187-192, Jan.2013.

[8]. McCarthy. "Manufacturing classification: Lessons from organisational systematic and biological taxonomy". Integrated Manufacturing Systems, 6(2), 37-48.1995.

[9]. L. McCarthy, M. Leseur, K. Ridgway, and N. Fieler, "Building a manufacturing cladogram," Int. J. Technol. Manag., vol. 13, no. 3, 269-286, 1997.

[10]. L. McCarthy, "Manufacturing strategies in the hand tool in industry". International Journal of Operations \& Production Management, 20(12), 14755-1487.2000

[11]. L. Mccarthy, \& K. Ridgway, "Cladistics a taxonomy for manufacturing organizations". Integrated Manufacturing Systems, 11(1), 16-29. 2000.

[12]. J.S. Baldwin, P.M. Allen, B.Winder, K. Ridgway, "Simulating the Cladistic Evolution of Manufacturing", in: Innovation: Management, Policy and Practice, Vol. 5, No. 2-3, 144-156. 2003

[13]. J.S Baldwin, P.M Allen, B. Winder, K. Ridgway, "Modelling Manufacturing Evolution: Thoughts of Sustainable Industrial Development", Journal of Cleaner Production, Vol. 13, No. 9, 887902.2004.

[14]. J.S. Baldwin, P.M. Allen, K. Ridgway, "An Evolutionary Complex Systems Decision-Support Tool for the Management of Operations", International Journal of Operations and Production Management, Vol. 30, No. 7, 700-720.2010

[15]. McCarthy, "Building a manufacturing cladogram".International Journal of Technology Management, 13(3), 269-286. 1997

[16]. T.N. AlGeddawy \& H.A ElMaraghy, "Symbiotic design of products and manufacturing systems using biological analysis", Proceedings of the 19th CIRP Design Conference-Competitive Design.2009

[17]. McCarthy, "Manufacturing classification: Lessons from organisational systematic and biological taxonomy", Integr. Manuf. Syst., vol. 6, no. 2, 37-48, 1995. 
[18]. L. McCarthy, "Manufacturing strategies in the hand tool industry, ’Int. J. Oper. Prod. Manag., vol. 20, no. 12, pp. 14755-1487, 2000.

[19]. L. Mccarthy, and K. Ridgway, Cladistics a taxonomy for manufacturing organizations, Integr. Manuf. Syst., vol. 11, no. 1, 1629, 2000

[20]. T. AlGeddawy, and H. ElMaraghy, "Assembly systems layout design model for delayed products differentiation", Int J Prod Res, vol. 48, 5281-5305.2010

[21]. A. Dwi Anggono,W. Adi Siswanto and B. Omar,"Finite Element Simulation for Springback Prediction Compensation," International
Journal on Advanced Science, Engineering and Information Technology, vol. 1, no. 5, pp. 564-569, 2011. [Online]. Available: http://dx.doi.org/10.18517/ijaseit.1.5.114

[22]. Qadir Bux,Ismail Abdul Rahman and Ahmad Mujahid Ahmad Zaidi,"Ogive Nose Hard Missile Penetrating Concrete Slab Numerical Simulation Approach," International Journal on Advanced Science, Engineering and Information Technology, vol. 1, no. 6, pp. 586-591, 2011. [Online]. Available: http://dx.doi.org/10.18517/ijaseit.1.6.118. 